\title{
Article \\ Different Countries, Common Support for Climate Change Mitigation: The Case of Germany and Poland
}

\author{
Zbigniew Bohdanowicz
}

check for

updates

Citation: Bohdanowicz, Z. Different Countries, Common Support for Climate Change Mitigation: The Case of Germany and Poland. Climate 2021, 9, 27. https://doi.org/10.3390/cli 9020027

Received: 17 December 2020

Accepted: 26 January 2021

Published: 28 January 2021

Publisher's Note: MDPI stays neutra with regard to jurisdictional claims in published maps and institutional affiliations.

Copyright: (C) 2021 by the author. Licensee MDPI, Basel, Switzerland. This article is an open access article distributed under the terms and conditions of the Creative Commons Attribution (CC BY) license (https:// creativecommons.org/licenses/by/ $4.0 /)$.
Economic Sciences, University of Warsaw, 00-241 Warsaw, Poland; zbohdanowicz@wne.uw.edu.pl; Tel.: +48-668-862-414

\begin{abstract}
There are numerous studies assessing the influence of individual sociological, political, and demographic factors on attitudes towards climate change. However, there is still a need for a deeper understanding of the reasons behind these attitudes and for research based on results from more than one country. This study empirically examines a range of psychosocial and demographic determinants of support for climate policy (renewable energy, energy efficiency and carbon tax) in Germany and Poland $(n=1969)$. The results show that the societies of both countries, despite significant differences in income, culture and political stance on climate change, similarly support implementation of climate policies. For both countries valid predictors of support are: awareness, emotional response to climate crisis, sense of control, and belief in effectiveness of solutions; the study also shows predictors relevant in only one country. Factor analysis identified similar dimensions of attitudes toward climate change in both countries. The main findings show that support for climate policy is high in both countries and that the public is ready to accept more ambitious climate goals. Despite the differences between the countries, a coherent climate policy seems justified. The study also shows differences between the countries and provides recommendations for policymakers.
\end{abstract}

Keywords: climate change; renewable energy; carbon tax; energy efficiency; public support; climate policy

\section{Introduction \\ 1.1. Background}

According to the Intergovernmental Panel on Climate Change (IPCC) report SR 1.5, greenhouse gas emissions must be reduced by $50 \%$ by 2030 . Such radical change would require widespread implementation of new regulations to facilitate the transformation of energy production, improve energy efficiency, internalize the negative effects of fossil fuel use (e.g., with a carbon tax) and enforce better management of land use.

Although the general public in European countries is aware of climate change (CC), the problem is often seen as less important than numerous other issues. People are generally familiar with the notion of CC and many claim that they support climate mitigation efforts but in practice only a small number take action to address it $[1,2]$.

The assessment of factors influencing perceptions of climate change has been the subject of research for the past few decades. Yet, despite the growing body of research on the subject, the mechanism driving support for CC mitigation still requires a deeper understanding. Many works have described trends in public perceptions but have not described their causes in more detail. An analysis of studies conducted since the 1980s shows that much of the research has been carried out in the United States, while we know less about the dynamics of attitudes in the rest of the world [3]. An analysis of 118 studies in this area shows that the majority of them assess a few selected factors and analyze data from only one country. Moreover, the results vary considerably and it is difficult to draw general conclusions about the drivers of support for climate mitigation policy [4]. An exception among studies assessing climate change perceptions is the work carried out by 
Poorting et al. using data from the European Social Survey for 22 countries. This study provides valuable insights about the importance of sociopolitical and demographic factors but the range of considered variables is limited [5].

This study focused on the psychosocial factors that shape attitudes towards climate change. It aimed to enhance understanding of the mechanisms driving these attitudes and support for mitigation policies. The study covered a range of factors indicated in the literature and assesses both the strength of their influence and interconnections between them. To go beyond the context of one country, the study was conducted in two EU states, Germany and Poland. With these two countries included in a single study, it was possible to assess which factors depend on the local context and which are more general, i.e., they apply in both cases. The level of support for climate mitigation policies was assessed in monetary terms, by contingent valuation, which facilitates the practical use of the results. The study was deliberately focused on CC mitigation, and not adaptation policies. Adaptation measures only have a local impact and, while important, will not be effective in the long term without climate mitigation. The study deliberately focused on climate policy rather than on individual actions. An effective response to climate change requires coordinated action, therefore support for climate policy was considered more important to the success of climate change mitigation than declarations about individual behavior. The study covers three policies currently implemented or discussed in the EU: developing renewable energy sources, instituting carbon taxes and improving energy efficiency. These are also the measures identified as key to successful decarbonization in the SP 1.5 report of the IPCC.

The paper is organized as follows: Section 1 introduces the subject of the article, presents climate policy in the EU and compares Germany and Poland. It also describes factors indicated in the literature as predictors of support for climate policy. Section 2 describes contingent valuation as the method of assessing the level of public support. It covers the methodology of the study, the questionnaire design and data collection method. Section 3 presents the results: differences in attitudes towards CC in Germany and Poland, an analysis indicating the variables determining the level of support for climate policies and a factor analysis of the variables in the model. Section 4 covers the discussion of the results, along with conclusions.

\subsection{Climate Policy in European Union (EU)}

The EU has developed a number of initiatives to decarbonize its economy. The EU aims to reduce greenhouse gas emissions by $40 \%$ by 2030 and to achieve full climate neutrality by 2050 [6]. Key actions taken by the EU to achieve this goal include the development of renewable energy sources and the improvement of energy efficiency [7]. In 2018 the EU generated 16\% of its energy from renewable sources and the target is to gradually increase this share to $32 \%$ in 2030 , until net zero emissions are achieved in 2050 (Renewable Energy Directive, 2018/2001/EU). According to the revised Directive on Energy Efficiency (2018/2002; European Commission), increased energy efficiency would reduce energy consumption by $32.5 \%$ by 2030 , compared to the 2007 base level. Furthermore, the EU has the emissions trading system (EU ETS), which is the world's first and still largest carbon market. This scheme efficiently reduces emissions from large energy-intensive businesses, such as power stations and industrial plants, and covers over 11,000 heavy energy-using installations. Its limitation is that it covers only $40 \%$ of the EU's greenhouse gas emissions, as it does not include smaller companies and individual consumers. Therefore, the European Commission plans to review and extend the scope of the EU ETS, based on the public consultation launched in July 2020 on energy taxation and the carbon border adjustment mechanism. Border carbon adjustment (BCA) is one of the mechanisms likely to be introduced by the EU. The BCA includes import and export adjustments that, on the one hand, require comparable payments for emissions embodied in imported and local goods and, on the other hand, exempt exported goods from their emissions costs [8]. 


\subsection{Socioeconomic Background and Climate Policy in Germany and Poland}

In many ways, Germany and Poland are similar. Both countries belong to the European Union, are located in its north-central part, are neighbors and have large populations. According to UN data, the population of Germany in 2020 is estimated to be 84 million people (the largest in the EU) and that of Poland 38 million people (the fifth largest in the EU). The two countries are strongly linked both economically and socially and Germany is a key trading partner for Poland, accounting for a quarter of its total imports and exports.

Yet these countries differ in a number of important features: Germany, a country with a developed and technologically advanced economy, is one of the founders of European integration, which led to the creation of the European Union. Poland is a post-Soviet country that has been undergoing transition to a market economy since 1989 and joined the EU in 2004. Germany is therefore a much wealthier country, with a GDP per capita nearly three times higher (\$46.4k per year in Germany vs. $\$ 15.7$ per year in Poland, 2019). The higher standard of living in Germany is confirmed by a 2.6-year higher life expectancy (81.9 years in Germany vs. 79.3 years in Poland). The countries also differ in population structure. Germany's population is older than Poland's (median age of 46 years vs. 42 years) and more people live in cities ( $76 \%$ vs. $60 \%$ ) [9]. The climate policies of the two countries differ as well. Germany has introduced an ecological tax reform as early as 1999, imposing ecological taxes on fossil fuels [10]. Moreover, Germany has made a serious effort to transform its energy sector towards the use of renewable energy sources [11,12]. On the one hand, this transformation has contributed to a $26 \%$ reduction in emission levels (2018 vs. 1990 base; International Energy Agency) and to the development of a renewable energy sector [13], but on the other hand, the high costs of the transformation are reflected in electricity prices, which are the highest in the EU (0.30 EUR/kWh in Germany vs. 0.21 EUR/kWh in EU-27; Consumer prices, Eurostat, 2020). Despite high energy prices and the extensive investments in the energy transformation, the German energy sector is still mainly based on fossil fuels and its carbon intensity is still high compared to the EU average. In this context, the controversial decommissioning of existing nuclear power stations should be mentioned. Among the critical voices addressing the German climate policy, there are some who are of the opinion that, due to technical constraints, it may be difficult or even impossible to carry out nuclear-free decarbonization of the energy sector on the basis of renewable energy sources alone [14]. Poland is a country dependent on heavy coal. It has reduced its $\mathrm{CO}_{2}$ emissions by $11 \%$ since 1990 , but the entire reduction occurred in the first decade after the transformation of the political system, and since the year 2000 emissions have been stable (International Energy Agency). Its share in electricity production from hard coal and lignite still exceeds $80 \%$; therefore, EU regulations aimed at excluding coal from electricity generation are perceived as a threat to energy security and the economic viability of the energy system $[15,16]$. For this reason, both the government and a part of the public in Poland are skeptical about the climate regulations being introduced by the EU [17]. For these reasons, the Polish government did not agree to the climate targets set at the Leaders' Summit in November 2019 and Poland remains the only EU country that opposed the goal of achieving climate neutrality in the EU by 2050. Despite the greenhouse gas fees associated with the generation of electricity from coal, the price of electricity for residential consumers is significantly lower in Poland than the EU average and twice as low as in Germany (0.15 EUR/kWh in Poland vs. 0.21 EUR/kWh in EU-27; Consumer prices, Eurostat, 2020). However, in the near future, due to the expected increase in the cost of emission permits and further regulations limiting the use of coal in the energy sector, electricity prices in Poland are likely to increase significantly.

\subsection{Factors Influencing Public Support for CC Mitigation}

In the studies examining the mechanisms behind disbelief and inaction, a number of factors have been identified: limited awareness of the problem [18], individual values and norms $[19,20]$, skepticism $[21,22]$, vulnerability to denial mechanisms [23,24], belief about limited direct impact of CC [25], perceived low risk related to CC, low self-efficacy [26] 
and others. Such a large spectrum of factors can be overwhelming and it is difficult to determine which are the most important. Therefore, the frequently mentioned factors driving support for climate policy were selected and included in this study.

It is agreed among psychologists that emotional responses have an adaptive function: people tend to react to events that trigger strong emotions [27-29]. It can be expected that the more the threat of CC seems invisible, distant and difficult to define, the less people worry about it and the weaker their emotional responses are [30]. People are prone to denial when faced with information that makes them feel guilty, helpless and afraid. This effect is reinforced in situations where accepting the information would interfere with norms that are important to a particular person or affect strong beliefs [21,31,32]. The denial mechanism is likely to be a predictor of support for CC mitigation, as this is one of the problems where it is difficult to find the right answer. Norgaard has done extensive qualitative work evaluating dimensions behind CC denial in particular and highlighted four key components: (1) emotions: fear, guilt and helplessness; (2) norms: being optimistic and maintaining control, positive assessment of oneself and one's country; (3) selective attention: avoiding information related to the problematic topic; (4) perspectival selectivity: rejection of responsibility for results [23].

Various studies demonstrate that understanding the Earth's climate and the physical mechanisms of the climate influence attitudes and concerns about this topic [33,34]. Studies indicate that people are more willing to act on climate change if they believe that it is real, human-caused, serious and solvable [35,36]. An important aspect of CC awareness entails understanding that the global climate is a public good and effective mitigation cannot be achieved without coordinated international action [37,38]. Also, attitudes towards the natural environment, as measured by the New Ecological Paradigm (NEP) [39] scale, are indicated by numerous studies as predictors of pro-environmental behavior and support for CC mitigation [40-43]. Conversely, skepticism about CC seems to be an important barrier to public support for CC mitigation [21,44,45].

$\mathrm{CC}$ is often perceived as a complex topic, one which is difficult for the average person to comprehend [46]. Therefore, it can be assumed that people with good cognitive skills will have a better understanding of it. Another important factor discussed in the literature is the feeling of control over the situation. Studies indicate that confidence in one's ability to act, both at an individual level and a broader level (through state or international organizations), is a significant factor that raises support for climate action $[18,33,34]$. Furthermore, social norms have the power to shape people's decisions and behavior, in that people's decisions are influenced by the behavior of those around them [47-49].

\section{Material and Methods}

\subsection{Measurement of Support for CC Mitigation Policies}

Economic studies that assess willingness to pay (WTP) for climate mitigation policies provide tangible estimates of the level of CC mitigation support, expressed in monetary terms [50-53], and provide information on various aspects of support for CC mitigation, such as the role of skepticism [44], beliefs about future climate conditions [54] or support for mitigation through forestry policy [55]. The significance of economic assessment for climate mitigation policies is also recognized by the IPCC, which sees economic evaluation as a practical tool to inform policy design. Estimating the value of non-market goods using contingent valuation has proven effective in assessing the value of a change in the quality of the environment. In this approach, respondents declare how much they are willing to pay to maintain or improve the environment in which they live, a specific natural resource or the global climate [50,56]]. WTP can be measured in a classic dichotomous choice referendum or by a question in which a respondent states his or her maximum acceptable payment for the environmental change. This study measured WTP by means of an open-ended question, which is less frequently used than contingent valuation surveys with closed questions (in the yes/no format recommended by the National Oceanic and Atmospheric Administration (NOAA)) [57]. The open-ended form was chosen because, 
according to the results of published studies, questions in a yes/no referendum format usually give significantly higher levels of estimation than open-ended ones $[52,58]$. The exact mechanism of this phenomenon is not completely known but may result from the tendency among respondents to accept an offer if they are given only two (yes or no) alternatives [59]. Taking into account the fact that the results of the study can be an indication of the value of climate mitigation policies for society, the study aimed to avoid overestimating this particular value.

An important aspect in stated preferences methods is consequentiality. Studies show that people are more likely to reveal their true preferences when they are convinced that their answers have at least a weak chance of influencing policy [60,61]. Therefore, the questionnaire should emphasize the relevance of the answers given and the chances of using the results of the survey in developing solutions implemented in practice.

\subsection{Data Collection}

The data were collected by means of an online, self-filled questionnaire (computerassisted web interviewing (CAWI)). Fieldwork was carried out in June 2019 by an external research agency (IQS Poland). The study was conducted in Germany and Poland on a random stratified sample (by gender, age, city size, region and education). Since the study concerned a complex subject and required smooth computer operation, the sample did not include people over 55 years old or those with only primary education. A total of 2015 interviews were conducted (1000 in Germany and 1015 in Poland), of which 46 records were removed following data quality evaluation. The analyses were conducted on a sample of 1969 interviews (970 in Germany and 999 in Poland).

The structure of the data collected in the study is shown in Table 1. Differences in the structure versus the census data for both countries stem from the fact that the survey was conducted among Internet users enrolled in dedicated research panels. Although the sample structure is different from the national census statistics, the characteristics of the samples from Germany and Poland are similar, so a comparison is justified.

Table 1. Structure of the sample compared to census data (2019).

\begin{tabular}{|c|c|c|c|c|}
\hline & Germany Census & German Sample & Poland Census & Polish Sample \\
\hline \multicolumn{5}{|l|}{ Gender } \\
\hline Male & $50.7 \%$ & $48.7 \%$ & $49.8 \%$ & $42.6 \%$ \\
\hline $\begin{array}{l}\text { Female } \\
\text { Age }\end{array}$ & $49.3 \%$ & $51.3 \%$ & $50.2 \%$ & $57.4 \%$ \\
\hline $18-24$ & $11.9 \%$ & $8.8 \%$ & $11.4 \%$ & $11.8 \%$ \\
\hline $25-29$ & $10.1 \%$ & $23.7 \%$ & $10.3 \%$ & $16.7 \%$ \\
\hline $30-39$ & $19.9 \%$ & $29.4 \%$ & $24.7 \%$ & $31.6 \%$ \\
\hline $40-49$ & $20.5 \%$ & $34.8 \%$ & $21.7 \%$ & $30.1 \%$ \\
\hline $50-59$ & $25.5 \%$ & $3.3 \%$ & $18.9 \%$ & $9.7 \%$ \\
\hline 60-65 & $12.1 \%$ & $0 \%$ & $13.1 \%$ & $0 \%$ \\
\hline \multicolumn{5}{|l|}{ City size } \\
\hline Village & $23.7 \%$ & $15.2 \%$ & $40.4 \%$ & $35.0 \%$ \\
\hline Up to $50 \mathrm{k}$ inhabitants & $35.6 \%$ & $26.4 \%$ & $24.1 \%$ & $20.2 \%$ \\
\hline $50-200 \mathrm{k}$ inhabitants & $15.5 \%$ & $22.4 \%$ & $16.0 \%$ & $19.7 \%$ \\
\hline $200-500 \mathrm{k}$ inhabitants & $8.5 \%$ & $29.7 \%$ & $8.3 \%$ & $11.2 \%$ \\
\hline $\begin{array}{l}\text { Above } 500 \mathrm{k} \\
\text { inhabitants }\end{array}$ & $16.8 \%$ & $6.4 \%$ & $11.2 \%$ & $13.8 \%$ \\
\hline Education & & & & \\
\hline $\begin{array}{l}\text { Primary and lower } \\
\text { secondary education }\end{array}$ & $37.6 \%$ & Not included & $37.6 \%$ & Not included \\
\hline $\begin{array}{l}\text { Upper secondary and } \\
\text { post-secondary }\end{array}$ & $23.3 \%$ & $37.6 \%$ & $35.9 \%$ & $35.2 \%$ \\
\hline Tertiary education & $39.1 \%$ & $62.4 \%$ & $26.5 \%$ & $64.7 \%$ \\
\hline
\end{tabular}


The survey was carefully designed so that its language would be accessible to those who did not know the subject of the survey well. Specialized terms, such as "climate change", "the impact of the introduction of mitigation policies on the economy" or "the state of the climate", were briefly described in simple language. The invitation to complete the survey highlighted the importance of the answers given and that the results might inform legal solutions that would affect all EU residents. Due to the serious subject matter of the survey, which required concentration, respondents were asked to reserve about 20-30 min to answer all of the questions.

At the end of the survey, the respondents evaluated the completed questionnaire with respect to three dimensions: interest in the subject, the clarity of the questions and commands and the length of the survey. The results show that the survey was evaluated well. Only $4 \%$ of respondents were not interested in the subject of the survey, $47 \%$ stated that they were interested and $49 \%$ claimed they were very interested. Questions and commands were rated as very understandable by $34 \%$ of respondents, as understandable by $60 \%$ and not understandable by $6 \%$. The questionnaire itself was assessed as too long by $15 \%$, as appropriate in length by $82 \%$ and as too short by $3 \%$ of respondents. The median time for completing the questionnaire was $26 \mathrm{~min}$.

\subsection{Research Design}

The questionnaire took into account the factors, described above, that determine support for CC mitigation policies. Attitudes included dimensions of climate change awareness, denial (based on dimensions identified by Norgaard [23]), skepticism (measured with a skepticism scale developed by L. Whitmarsh [62]) and biosphere values (based on the NEP scale by Dunlap [39]). Both descriptive and prescriptive norms were measured; norm internalization was also evaluated. Behavioral control was measured by questions about perceived barriers to climate action and level of control over the climate situation. General cognitive abilities were assessed with the Cognitive Reflection Test [63]. This short test, containing only three questions, is widely used as an indicator of cognitive ability and rational thinking [64]. Basic sociodemographic characteristics of respondents were also included. The list of variables used in the research and the hypothesized effect on the level of support for climate policies is given in Table 2 .

The survey assumed that a continued pursuit of the ambitious targets for emission reductions will require financial expenditure in the future, which will be reflected in higher financial burdens for individual consumers-in the form of additional taxes or higher prices of consumer goods. Therefore, the respondent assessed the EU's existing climate policy and decided how much of a financial burden on his/her budget he/she would be willing to accept to continue this policy and meet the reduction targets. The intention of this measurement was to assess the net financial burden of continued climate policy that consumers are willing to accept, regardless of the specific tools that will eventually be used to achieve the emissions reduction target.

Three specific climate policies were presented for assessment in the study (renewable energy, carbon tax, energy efficiency), as these actions are listed in the IPCC SR 1.5 report as essential to achieve necessary emission reductions. In the EU these policies are already being undertaken or planned in the near future and their implementation will have an impact on the financial situation of individual consumers [6]. Respondents were informed that further development of renewable energy would need subsidies from the state budget and that improving energy efficiency would require the introduction of stricter, and therefore more costly, energy standards for producers of consumer goods and for buildings. A carbon tax was presented in the form of a general fee on the use of fossil fuels, in line with current EU plans to extend the existing EU ETS to cover emissions from personal consumption as well. Taxation of $\mathrm{CO}_{2}$ emissions in the form of the EU ETS was not assessed because it is a mechanism that taxes only the largest, industrial emitters of greenhouse gases (around 11,000 companies in the EU) and this mechanism could be difficult to understand for the average person. 
Table 2. Variables hypothesized to determine likelihood of supporting climate change (CC) mitigation.

\begin{tabular}{|c|c|c|}
\hline Variable & Question/Description & $\begin{array}{l}\text { Hypothesized Effect on CC } \\
\text { Mitigation Support }\end{array}$ \\
\hline $\mathrm{CC}$ as a global risk & $\begin{array}{l}\text { Q: Which from the following list of global problems } \\
\text { would you include among those to be tackled first? } \\
\text { Please select a maximum of five ->chosen item } \\
\text { "Anthropogenic climate change" }\end{array}$ & Positive \\
\hline $\begin{array}{l}\text { CC_Impact_now } \\
\text { CC_Impact_20 } \\
\text { CC_Impact_50 }\end{array}$ & $\begin{array}{l}\text { Q: What is the impact of climate change on the life of } \\
\text { an average German/Pole at the moment/in } 20 \\
\text { years/in } 50 \text { years? } \\
\text {->answer on a five-point scale }\end{array}$ & Positive \\
\hline Maximum temperature increase & $\begin{array}{l}\text { Q: In your opinion, what maximum increase in the } \\
\text { average temperature on Earth, compared to the period } \\
\text { before the industrial revolution (1850-1900), should be } \\
\text { considered safe: } \\
\text {->range from }+1.0^{\circ} \mathrm{C} \text { to }+5.1^{\circ} \mathrm{C} \text { and more }\end{array}$ & Negative \\
\hline Denial & $\begin{array}{c}\text { Nine statements evaluated on a five-point scale } \\
\text { estimating level of denial on four dimensions: } \\
\text { emotions, norms, selective attention and } \\
\text { perspectival selectivity }\end{array}$ & Negative \\
\hline Public good & $\begin{array}{l}\text { Evaluation of the awareness that the climate is a global } \\
\text { public (common) good }\end{array}$ & Positive \\
\hline Skepticism & $\begin{array}{l}\text { Result on a skepticism scale, based on } 17 \text { statements } \\
\text { evaluated on a five-point scale }\end{array}$ & Negative \\
\hline NEP scale & Result on a full NEP scale (15 statements) & Positive \\
\hline CC awareness & $\begin{array}{c}\text { Q: How do you assess your level of awareness of } \\
\text { global warming (otherwise known as } \\
\text { "climate change")? }\end{array}$ & Positive \\
\hline IPCC awareness & Q: How familiar are you with the IPCC? & Positive \\
\hline CC causes & $\begin{array}{l}\text { Evaluation of objective knowledge of the causes of } \\
\text { climate change based on the answers to six questions }\end{array}$ & Positive \\
\hline CC impacts & $\begin{array}{l}\text { Evaluation of objective knowledge of the effects of } \\
\text { climate change based on the answers to } \\
\text { eight questions }\end{array}$ & Positive \\
\hline Social norms & $\begin{array}{l}\text { Four statements evaluating norms related to } \\
\text { CC mitigation }\end{array}$ & Positive \\
\hline Control & $\begin{array}{l}\text { Evaluation of the feeling of control over the climate } \\
\text { situation, based on the answers to six questions }\end{array}$ & Positive \\
\hline Policy effectiveness & $\begin{array}{l}\text { Perceived effectiveness of evaluated policies } \\
\text { (renewable energy, carbon tax, energy efficiency) }\end{array}$ & Positive \\
\hline Cognitive Reflection Test & $\begin{array}{c}\text { Person's cognitive ability, measured with the } \\
\text { Cognitive Reflection Test }\end{array}$ & Positive \\
\hline Sociodemographic variables & $\begin{array}{l}\text { Gender, age, education, city size, financial situation, } \\
\text { savings, faith in God, country }\end{array}$ & \\
\hline
\end{tabular}

At the beginning of the survey, respondents were given a short description of the current climate situation and read information describing the objectives and potential costs of climate policy currently implemented in the EU. Respondents were informed that their answers could have an impact on future climate change mitigation measures implemented in the EU. Next, they were asked to state the maximum cost they would accept for the implementation of CC mitigation policies. The declared amount would have to be covered each month for a period of the next ten years. WTP thus defined was estimated with an open-ended question, where a " 0 " value was accepted. To ensure that respondents had given a reasoned answer, they were asked to confirm the correctness of the stated value. In the next step, they were asked to define the preferred split of the stated value among three policies: (1) support for the development of renewable energy, (2) a carbon tax on $\mathrm{CO}_{2}$ emissions and (3) enhancement of energy efficiency. The exact wording of the 
questions and information presented to respondents in this section of the survey is shown in Appendix A.

The research examined the relationship between the variables listed in Table 2 and support for climate policies, measured by WTP. The analysis was based on the linear regression model, which explained the WTP log values of the WTP as stated by the respondents. It was assumed that the logarithm of a given respondent's true WTP was expressed by a linear function of his or her attitudes, values and sociodemographic characteristics:

$$
\log (\mathrm{WTP})=\alpha+\beta^{\prime} X+\varepsilon
$$

where $\log (\mathrm{WTP})$ is a respondent's true but unobserved WTP, $\mathrm{X}$ is a vector of variables measured in the study and $\varepsilon$ represents a normally distributed error term. WTP values between 0 and 1 were replaced with a value of 0 .

\section{Results}

The average valuation of CC mitigation policies was found to be 53 EUR monthly in Germany and 98 PLN (about 23 EUR equivalent) in Poland. Only 7\% of respondents did not declare a positive value of support for CC mitigation policies. The highest support was expressed for the development of renewable energy ( $47 \%$ of the declared amount in Germany; $50 \%$ of the declared amount in Poland). Approximately one-third of the stated amount was allocated to enhancement of energy efficiency (35\% in Germany; $33 \%$ in Poland), while the smallest part was spent on introducing a carbon tax (18\% in Germany; $16 \%$ in Poland).

A comparison of attitudes to climate change in Germany and Poland (Figure 1) shows that in Germany there is a lower level of denial and skepticism, a higher awareness of the causes and effects of climate change and higher sensitivity to ecological values, as measured by the NEP scale. The countries surveyed do not differ in terms of awareness that the climate is a global public good. It is worth noting that the perception of the effectiveness of climate policies is higher in Poland, a country which implements them on a much smaller scale than Germany.

Regression analysis, assessing the links between the factors and the level of support for climate policies, was run separately on the samples collected in Germany and Poland to obtain estimates of $\alpha$ and $\beta$ for each country. The results are presented in Table 3 .

Based on the model estimation, some factors were found to be predictors of CC mitigation support in both countries (level of control, effectiveness of carbon tax and emotions), while others are important predictors in only one country (skepticism and savings in Germany; education, understanding the causes and effects of CC and effectiveness of renewable energy in Poland). Interestingly, some variables indicated in the literature as valid predictors of support for CC mitigation proved to be non-relevant for both countries (NEP, CRT).

Pearson's correlation analysis showed relatively low correlation among variables. Only in occasional cases did the correlation coefficient exceed 0.50. For both countries, there were relatively strong correlations between the level of skepticism and the NEP scale and between skepticism and social norms. 


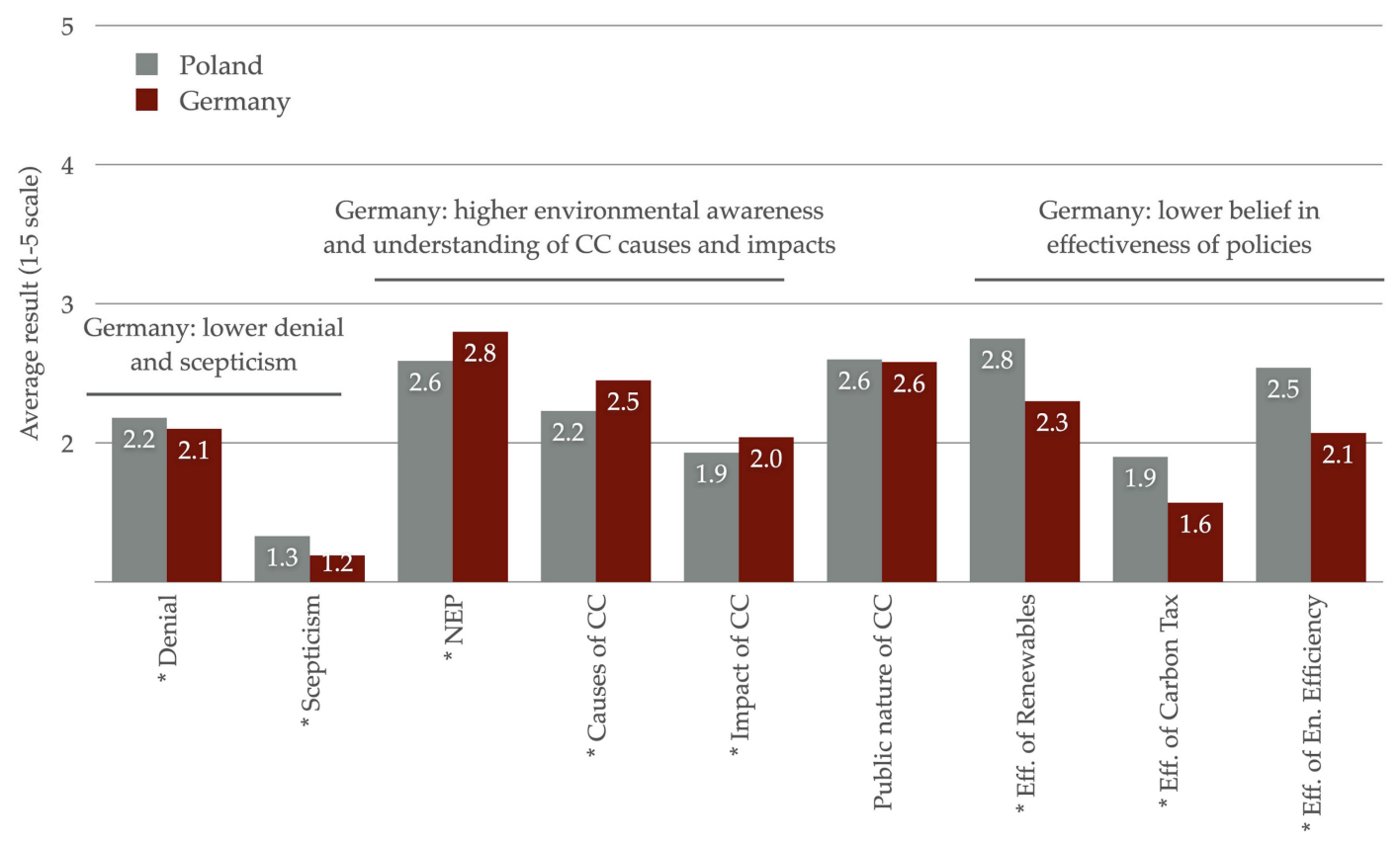

Figure 1. Comparison of average answers on a five-point scale in Poland and Germany. Statistically significant variables, at $p<0.05$, are marked with * (Student's $t$-test).

Since the study included a number of variables that potentially affect the level of support for CC mitigation, verification of their mutual relationship was possible. For this purpose, a factor analysis with Varimax rotation was performed on the variables included in the study. The KMO test value was 0.815 for data from Germany and 0.797 for data from Poland. The significance of Bartlett's test of sphericity was below 0.001 for both samples. In both cases, five components were distinguished, explaining $66 \%$ of the variance for data from Germany and $65 \%$ of the variance for data from Poland.

The results of the factor analysis, presented in Table 4, show a high similarity between the components specified for data from Germany and Poland. In both countries, the first component is formed by the results characteristic of climate change skepticism: a low score on the NEP scale, a low awareness of the causes and effects of CC and a high level of skepticism (and, in Poland, a high score on the perspectival selectivity scale also). The second component is characterized in both countries by variables describing positive attitudes towards CC mitigation: a high sense of control, high social norms regarding climate and a low level of skepticism. The third component is characterized by a subjective belief in (a) one's own strong knowledge of climate change and (b) the awareness of IPCC work. The fourth component consists of variables that describe selective attention (in Poland), perspectival selectivity (in Germany) and-in both countries-low awareness that climate is a global public good. The fifth component is identical for both countries and is defined by the variable describing emotional response to climate change.

Regression analysis, which explains the level of support for climate policy through the components defined in the factor analysis (Table 5), showed that all components created for the German sample are significant predictors of support for climate policy. In the case of Poland, all components except for the fourth are significant. 
Table 3. Results of linear regression conducted separately on samples from Germany and Poland. Statistically significant variables, at $p<0.05$, are marked with *.

\begin{tabular}{|c|c|c|c|c|c|c|}
\hline \multirow[t]{2}{*}{ Dependent Variable: $\log (\mathrm{WTP})$} & \multicolumn{3}{|c|}{$\begin{array}{c}\text { German Sample }(n=970) \\
R^{2} \text { adj. }=0.288 ; \text { Durbin-Watson }=1.930\end{array}$} & \multicolumn{3}{|c|}{$\begin{array}{c}\text { Polish Sample }(n=999) \\
R^{2} \text { adj. }=0.284 ; \text { Durbin }- \text { Watson }=2.114\end{array}$} \\
\hline & Beta (std) & SE & $p$ & Beta (std) & SE & $p$ \\
\hline Constant & & 0.880 & 0.000 * & & 0.891 & 0.000 * \\
\hline $\mathrm{CC}$ as a global risk & 0.064 & 0.093 & $0.042 *$ & 0.121 & 0.095 & $0.000 *$ \\
\hline IPCC awareness & 0.104 & 0.045 & $0.002 *$ & 0.088 & 0.055 & 0.007 * \\
\hline Emotions (denial scale) & 0.098 & 0.072 & 0.001 * & 0.093 & 0.079 & $0.002 *$ \\
\hline Control & 0.132 & 0.059 & $0.000 *$ & 0.156 & 0.093 & $0.000 *$ \\
\hline Effectiveness of carbon tax & 0.146 & 0.044 & $0.000 *$ & 0.153 & 0.042 & $0.000 *$ \\
\hline Causes & 0.01 & 0.109 & 0.766 & 0.095 & 0.108 & $0.002 *$ \\
\hline Education & -0.009 & 0.061 & 0.748 & -0.071 & 0.061 & $0.013 *$ \\
\hline CC awareness & -0.027 & 0.024 & 0.409 & -0.069 & 0.027 & 0.035 * \\
\hline Social norms & 0.03 & 0.072 & 0.384 & 0.120 & 0.084 & 0.001 * \\
\hline Financial situation & 0.041 & 0.065 & 0.195 & 0.063 & 0.075 & 0.044 * \\
\hline City size & 0.037 & 0.021 & 0.192 & -0.065 & 0.02 & $0.023 *$ \\
\hline $\begin{array}{l}\text { Perceived effectiveness of } \\
\text { energy efficiency }\end{array}$ & 0.059 & 0.056 & 0.102 & 0.095 & 0.058 & $0.006^{*}$ \\
\hline $\begin{array}{l}\text { Perceived effectiveness of } \\
\text { renewables }\end{array}$ & 0.063 & 0.053 & 0.084 & -0.108 & 0.056 & $0.002 *$ \\
\hline Age & -0.057 & 0.005 & 0.067 & -0.070 & 0.005 & 0.027 * \\
\hline Public good & 0.063 & 0.072 & 0.030 * & 0.026 & 0.073 & 0.352 \\
\hline Skepticism & -0.144 & 0.090 & $0.003 *$ & -0.064 & 0.098 & 0.158 \\
\hline Savings & 0.094 & 0.098 & 0.003 * & 0.055 & 0.099 & 0.079 \\
\hline Children & 0.065 & 0.046 & 0.034 * & 0.054 & 0.045 & 0.07 \\
\hline Impacts & 0.009 & 0.066 & 0.808 & -0.054 & 0.072 & 0.101 \\
\hline NEP scale & 0.022 & 0.106 & 0.580 & 0.049 & 0.124 & 0.218 \\
\hline $\begin{array}{l}\text { Perspectival selectivity } \\
\text { (denial scale) }\end{array}$ & -0.024 & 0.050 & 0.447 & 0.043 & 0.056 & 0.159 \\
\hline CC impact in 20 years & -0.019 & 0.076 & 0.683 & -0.042 & 0.086 & 0.432 \\
\hline Gender & 0.023 & 0.086 & 0.423 & 0.038 & 0.098 & 0.219 \\
\hline CC impact now & -0.020 & 0.043 & 0.537 & 0.031 & 0.045 & 0.368 \\
\hline CC impact in 50 years & 0.054 & 0.075 & 0.244 & 0.080 & 0.076 & 0.092 \\
\hline Faith in God & 0.012 & 0.031 & 0.683 & 0.012 & 0.038 & 0.684 \\
\hline Maximum temperature & 0.021 & 0.025 & 0.48 & 0.011 & 0.02 & 0.687 \\
\hline Cognitive Reflection Test & -0.014 & 0.039 & 0.635 & -0.003 & 0.046 & 0.913 \\
\hline Norms (denial scale) & -0.045 & 0.058 & 0.131 & -0.014 & 0.067 & 0.638 \\
\hline Selective attention (denial scale) & -0.047 & 0.053 & 0.165 & 0.002 & 0.058 & 0.962 \\
\hline
\end{tabular}


Table 4. Factor analysis of variables included in the research. Table displays rotated component matrix; coefficients below 0.5 are not shown.

\begin{tabular}{|c|c|c|c|c|c|c|c|c|c|c|}
\hline \multirow{3}{*}{$\begin{array}{c}\text { Rotated Component Matrix } \\
\text { Component: } \\
\% \text { of Variance: }\end{array}$} & \multicolumn{5}{|c|}{ German Sample $(\mathrm{n}=970)$} & \multicolumn{5}{|c|}{ Polish Sample $(\mathrm{n}=999)$} \\
\hline & 1 & 2 & 3 & 4 & 5 & 1 & 2 & 3 & 4 & 5 \\
\hline & $18.9 \%$ & $16.4 \%$ & $11.5 \%$ & $10.2 \%$ & $9.0 \%$ & $17.4 \%$ & $17.3 \%$ & $12.3 \%$ & $9.4 \%$ & $8.6 \%$ \\
\hline Impacts & -0.813 & & & & & -0.663 & & & & \\
\hline NEP scale & -0.727 & & & & & -0.618 & & & & \\
\hline Skepticism & 0.620 & -0.540 & & & & 0.564 & -0.563 & & & \\
\hline Selective attention (denial scale) & & -0.683 & & & & & & & -0.615 & \\
\hline Norms (denial scale) & & -0.669 & & & & & & & & \\
\hline Control & & 0.619 & & & & & 0.812 & & & \\
\hline CC awareness & & & 0.853 & & & & & 0.840 & & \\
\hline IPCC awareness & & & 0.838 & & & & & 0.837 & & \\
\hline Perspectival selectivity (denial scale) & & & & -0.774 & & 0.556 & & & & \\
\hline Public good & & & & -0.627 & & & & & -0.761 & \\
\hline Emotions (denial scale) & & & & & 0.923 & & & & & 0.940 \\
\hline
\end{tabular}


Table 5. Linear regressions conducted separately for samples from Germany and Poland, explaining support for climate policy as measured by $\log (\mathrm{WTP})$ through the components identified in the factor analysis. Statistically significant variables, at $p<0.05$, are marked with *.

\begin{tabular}{|c|c|c|c|c|c|c|}
\hline \multirow[t]{2}{*}{ Dependent Variable: $\log (\mathrm{WTP})$} & \multicolumn{3}{|c|}{$\begin{array}{c}\text { German Sample }(n=970) \\
R^{2} \text { adj. }=0.221 ; \text { Durbin-Watson }=1.888\end{array}$} & \multicolumn{3}{|c|}{$\begin{array}{c}\text { Polish Sample }(n=999) \\
R^{2} \text { adj. }=0.195 ; \text { Durbin-Watson }=2.059\end{array}$} \\
\hline & Beta (std) & SE & $p$ & Beta (std) & SE & $p$ \\
\hline (Constant) & & 0.42 & $0.000 *$ & & & \\
\hline Component 1 (Germany) & -0.160 & 0.42 & $0.000 *$ & & & \\
\hline Component 2 (Germany) & 0.332 & 0.42 & $0.000 *$ & & & \\
\hline Component 3 (Germany) & -0.118 & 0.42 & 0.000 * & & & \\
\hline Component 4 (Germany) & -0.092 & 0.42 & 0.001 * & & & \\
\hline Component 5 (Germany) & -0.259 & 0.42 & $0.000 *$ & & & \\
\hline (Constant) & & & & & 0.45 & 0.000 * \\
\hline Component 1 (Poland) & & & & -0.123 & 0.45 & 0.000 * \\
\hline Component 2 (Poland) & & & & -0.361 & 0.45 & 0.000 * \\
\hline Component 3 (Poland) & & & & 0.064 & 0.45 & 0.025 * \\
\hline Component 4 (Poland) & & & & -0.037 & 0.45 & 0.195 \\
\hline Component 5 (Poland) & & & & -0.221 & 0.45 & 0.000 * \\
\hline
\end{tabular}

\section{Discussion}

Despite significant differences between the countries in terms of climate change awareness, attitudes towards the environment and assessment of the effectiveness of climate policies, the survey showed that in both Germany and Poland there is strong support for CC mitigation. The fact that $93 \%$ of the respondents accepted certain additional costs related to the introduction of the policies shows that the public is ready to cover at least some of the decarbonization costs, both in Germany and Poland. It indicates that the new, more ambitious climate policy goals proposed by the European Commission in the 2030 Climate Target Plan to increase the emissions reduction target from $40 \%$ to $55 \%$ by 2030, versus 1990 levels, are likely to be well-received by the public in individual member states. This result confirms data obtained by Bernauer and Gampfer, who concluded on the basis of a survey conducted in the USA and India that, in both countries, despite significant differences in terms of their GDP levels, societies are ready to accept more rapidly implemented and ambitious climate policies than those currently being realized by politicians [65].

Out of the three policies evaluated, the development of renewable energy sources, to which the respondents in both countries chose to allocate half of the stated amount of funding, had the greatest support. This result is not necessarily self-evident; it does show, however, that the attitudes of both societies are similar, even though the attitudes of their governments differ. Overall, the comparable degrees of support in both countries for the three policies suggest that these preferences may be similar in other European countries as well.

Similarly as in the other studies [40,66], the introduction of a carbon tax had the lowest support, which indicates that the implementation of this solution could be particularly difficult and confirms the negative attitudes of most societies towards taxes, regardless of their purpose [67]. This is an important observation in the context of the planned extension of the existing EU ETS with a carbon tax on individual consumers. If such a solution is introduced, it would be worth considering the inclusion of a redistributive mechanism in the tax and emphasizing this aspect in the communication to the public. An alternative may be a carbon tax in a form similar to the "fee-and-dividend" proposed by James Hansen [68], which involves returning emission fees to society. By returning a portion or the entire tax collected to the public in the form of an equal dividend for everyone, a significant part of 
the public would be a net beneficiary of such an arrangement and the tax rate would be progressive [69].

The regression analysis showed that in both of the samples studied, awareness of climate crisis, emotional response, sense of control over the situation and belief in effectiveness of solutions are important predictors of support for climate policy. These factors describe universal aspects of dealing with problems effectively, i.e., being aware of the problem, motivated to act and aware of effective solutions. Country-specific factors indicate local characteristics that influence attitudes towards climate change. In Poland, where awareness of the climate crisis is lower, attitudes towards climate policy seem to depend on the general knowledge of the subject. Therefore, support for CC mitigation is lower in smaller cities or among less-educated people. In Germany, where awareness of the climate crisis is higher, support for climate policy depends more on individual attitudes to this threat and to climate policies carried out by the government in recent decades. This shows that similar climate policies can be applied in both countries but their communication should be tailored to the specifics of each country. In Germany, it is important to address the potential disappointment with the long and costly energy transition by building confidence that decarbonization of the energy sector is the right way forward. In Poland, it is important to educate the public about climate change, especially the less-informed part of society.

Several factors that were considered drivers of support in other studies of CC mitigation attitudes proved to be not relevant in this study (e.g., perception of climate change impacts, NEP scale, Cognitive Reflection Test). Perhaps these variables would prove relevant in studies carried out in other countries. However, this study suggests that other factors may be more important predictors of support.

The factor analysis of variables describing attitudes towards climate change, carried out independently on both samples, identified five components with very similar structures. The implication is that, despite significant differences between the countries studied, the main dimensions on which attitudes towards climate policy in Germany and Poland are built are similar. It would be valuable to check whether a similar result would also be obtained in other countries but these results already provide evidence that the dimensions determining attitudes to CC may be similar. In both countries studied, the array of variables used in the study could be reduced to five dimensions describing: skepticism about CC, attitudes towards climate policy, subjective belief about CC awareness, selective attention related to information about CC (linked to the mechanism of information denial) and emotional response to the climate crisis.

This study has certain limitations. First, the survey was carried out in only two EU countries. It can be assumed that the results obtained in culturally different countries (e.g., in southern Europe) could differ considerably. Second, although a wide range of factors was included in the study, in total they explain less than 30\% of the variance of WTP for climate policy implementation. Thus, there may be other important factors influencing the level of support for climate policy that were not included in this study. Third, accurately measuring WTP in a contingent valuation study of a global environmental resource is a serious challenge. Despite efforts to ensure that WTP is measured in accordance with the standards for contingent valuation studies, such as a clear statement of what is being paid for and what the result of the evaluated action will be, the method used does affect the results. Fourth, the applied regression method does not show a causal effect relationship but only a correlation between variables. It would therefore be advisable to analyze the support for climate policy by means of a more advanced model, describing cause-effect relationships. Next, the survey did not measure actual behavior but only the intention to support the implementation of climate policies. The discrepancies between intentions and actual behavior in this case may be crucial and this is certainly an area worth further study.

Limitations of the research results also apply to the surveyed sample. The survey did not take into account the opinions of people older than 55 years or with education lower than secondary education. Moreover, conducting the survey in the form of an online 
questionnaire results in overrepresentation of people who use computers and more often have white-collar jobs. For this reason, the results of the study should be treated as referring to a significant, but still specific, part of society-young and middle-aged people with better than average education who are more likely to be white-collar workers. It can be assumed that these are people with a higher than average financial capacity, so acceptance of the additional costs of climate change mitigation may be higher among them than the average in the respective society.

\section{Conclusions}

The study show that populations in countries that differ significantly in their income levels, culture and the attitudes of their governments may be similarly supportive of measures to mitigate climate change. Analysis of psychosocial factors revealed that the main dimensions of attitudes toward climate change are also similar in these countries.

The findings reveal that in Germany and Poland most people are in favor of climate policy and are ready to cover additional cost of mitigation measures. This indicates that, contrary to the concerns of decision-makers and experts, societies in these countries are willing to support the introduction of such policies, even if it would involve certain costs. It can therefore be expected that setting new, more ambitious targets for climate policy in the EU will be understood and accepted by the majority of the societies in the member states.

In both countries, the level of support is higher when there is greater climate change awareness, emotional response and belief in the effectiveness of policies. This shows that awareness of the problem, considering it as affecting oneself personally and having confidence that there are effective methods of solving the problem can be universal dimensions that increase support for climate policy implementation.

Factor analysis shows that, in both Germany and Poland, attitudes towards climate policies are built on similar dimensions related to climate skepticism, evaluation of climate policy, CC awareness, information denial and emotional response. This suggests that, in countries as distinct from each other as Germany and Poland, the main dimensions on which society's approach to climate change mitigation is determined are similar. Therefore, it can be concluded that the execution of a coherent climate policy in the EU is justified. It seems that climate policy does not have to be tailored to specific member states due to local differences in attitudes towards climate change, such as the level of climate awareness, previous experience with climate policy and cultural values. Instead, these differences should rather be reflected in the communication strategy implemented in each country explaining the rationale for climate change mitigation actions.

The study showed that support for the three policies evaluated is similar in Germany and Poland, with carbon tax receiving the lowest support. This suggests that carbon tax on individual consumption, planned for introduction in the EU, should be in the form of redistributive mechanisms, such as fee-and-dividend, rather than the standard tax burden. Such a solution should be met with greater acceptance by societies.

Taking into account the limitations of the study, resulting from the fact that it was based on data from two selected EU countries and from the specificity of the surveyed sample (Internet users, aged up to 55, with at least secondary education), it would be advisable to verify the obtained results in subsequent studies covering other countries and conducted using research methods that include a wider part of the population.

Funding: This study was financed by the National Science Centre in Poland (Narodowe Centrum Nauki, ul. Twardowskiego 16, 30-312 Kraków, Polska) under a Grant: Preludium 13, PRO2017/25/N/HS4/01055.

Data Availability Statement: The data presented in this study are openly available in Mendeley Repository at http:/ /dx.doi.org/10.17632/cb5v64zd45.3, (DOI:10.17632/cb5v64zd45.3).

Acknowledgments: I express my gratitude for the support during the preparation of this manuscript to Mikołaj Czajkowski, to the National Science Centre for the grant for this study and to the adminis- 
trative department of the Faculty of Economic Sciences at University of Warsaw for their support in processing this project.

Conflicts of Interest: The authors declare no conflict of interest. The funders had no role in the design of the study; in the collection, analyses, or interpretation of data; in the writing of the manuscript, or in the decision to publish the results.

\section{Appendix A}

Descriptions of CC situation, CC mitigation policies in the EU and the wording of a question about WTP for application of CC mitigation policies.

1. Description of a current climate situation

Currently, the average temperature on Earth is $1.0^{\circ} \mathrm{C}$ higher than in the pre-industrial era (1850-1900) and the rate of temperature increase is accelerating. The temperature rises by about $0.13{ }^{\circ} \mathrm{C}$ per decade and above the land and closer to the poles this change is faster.

An important change associated with climate change is the more frequent occurrence of weather anomalies and natural disasters (storms, downpours, droughts, high temperature variability).

Climate scientists agree that in order to avoid catastrophic consequences, it is necessary to limit the increase in the Earth's average temperature to a level up to $2^{\circ} \mathrm{C}$ higher than in the pre-industrial period (1850-1900), i.e., $1{ }^{\circ} \mathrm{C}$ more than today.

In order to keep the temperature below this limit, greenhouse gas emissions (mainly carbon dioxide, $\left(\mathrm{CO}_{2}\right)$ ) from the combustion of fossil fuels must be significantly reduced. This requires regulations and investments.

Effective climate change mitigation requires coordinated action by all countries in the world. The EU is the source of $10 \%$ of global $\mathrm{CO}_{2}$ emissions, so reducing emissions in the EU alone will not be enough. However, by demonstrating, through the example of the relatively rich EU, that with appropriate regulations and low-carbon technologies it is possible to effectively reduce $\mathrm{CO}_{2}$ emissions, it may be easier to copy these best practices in other parts of the world.

(For example, the strong support for wind and photovoltaic energy in Germany over the last decade has led to the development of renewable energy production technologies. As a result, the development of renewable energy has accelerated globally).

2. Description of CC mitigation policies in the EU

In a moment you will be asked to evaluate the actions currently being implemented in the EU. Their goal is to reduce $\mathrm{CO}_{2}$ emissions and limit the increase in the average Earth's temperature to $2{ }^{\circ} \mathrm{C}$ above pre-industrial levels and $1{ }^{\circ} \mathrm{C}$ higher than today.

These actions are:

1. Support for the development of renewable energy sources

The development of renewable energy sources (e.g., solar, wind, hydro, geothermal, biomass) reduces dependence on fossil fuels but requires subsidies from the state budget.

2. Carbon tax (tax on fossil fuels: oil, gas, coal)

A carbon tax is imposed on all fossil fuels-oil, coal and gas. It increases the cost of energy from the burning of fossil fuels and, indirectly, prices of goods.

3. Energy efficiency

Higher energy efficiency standards require that household appliances use less electricity, cars burn less fuel and buildings have good thermal insulation. This means stricter standards for manufacturers and can indirectly lead to higher commodity prices.

\section{Support for CC mitigation}

The exact cost of climate change mitigation measures is not yet known but part of the cost will be felt by households-through increased commodity prices or taxes.

The EU estimates that mitigating climate change will reduce carbon emissions by $30 \%$ by 2030 , reduce the EU's dependence on fossil fuels and improve air quality. The long-term goal is to fully phase out the burning of fossil fuels in the EU by 2050 . 
While answering, please assume that the costs of implementing these measures will be felt over the next ten years. Your answers may have an impact on what climate change mitigation measures will be implemented in the EU in the future.

(1) Please indicate what the maximum acceptable increase in your personal monthly expenses related to the implementation of these climate change mitigation measures is?

[Amount to be entered]

(2) How do you think the resources allocated to climate change mitigation should be divided between these three policies?

(a) Development of renewable energy sources.

(b) Introduction of a carbon tax.

(c) Improving energy efficiency.

\section{References}

1. Poortinga, W.; Corner, A.J.; Arnold, A.; Böhm, G.; Mays, C. European Perceptions of Climate Change (EPCC): Topline Findings of a Survey Conducted in Four European Countries in 2016; Cardiff University: Cardiff, UK, 2017.

2. Kundzewicz, Z.W.; Matczak, P. Climate change regional review: Poland. WIREs Clim. Chang. 2012, 3, 297-311. [CrossRef]

3. Capstick, S.; Whitmarsh, L.; Poortinga, W.; Pidgeon, N.; Upham, P. International trends in public perceptions of climate change over the past quarter century: International trends in public perceptions of climate change. Wiley Interdiscip. Rev. Clim. Chang. 2015, 6, 35-61. [CrossRef]

4. Kyselá, E.; Ščasný, M.; Zvěřinová, I. Attitudes toward climate change mitigation policies: A review of measures and a construct of policy attitudes. Clim. Policy 2019, 19, 878-892. [CrossRef]

5. Poortinga, W.; Whitmarsh, L.; Steg, L.; Böhm, G.; Fisher, S. Climate change perceptions and their individual-level determinants: A cross-European analysis. Glob. Environ. Chang. 2019, 55, 25-35. [CrossRef]

6. Directorate-General for Climate Action Going climate-neutral by 2050. In A Strategic Long-Term Vision for a Prosperous, Modern, Competitive and Climate-Neutral EU Economy; European Commission: Brussels, Belgium, 2019. [CrossRef]

7. Delbeke, J.; Vis, P. (Eds.) EU Climate Policy Explained; Routledge: London, UK, 2015; ISBN 9781317338123.

8. Droege, S.; Fischer, C. Pricing Carbon at the Border: Key Questions for the EU. ifo DICE Rep. 2020, 18, 30-34.

9. World Population Prospects-Population Division-United Nations. Available online: https://population.un.org/wpp/ (accessed on 13 January 2021).

10. Mehling, M. Germany's Ecological Tax Reform: A Retrospective. In Environmental Sustainability in Transatlantic Perspective: A Multidisciplinary Approach; Achilles, M., Elzey, D., Eds.; Palgrave Macmillan UK: London, UK, 2013; pp. 91-103. ISBN 9781137334480 .

11. Radtke, J.; Kersting, N. (Eds.) Energiewende: Politikwissenschaftliche Perspektiven; Springer: Wiesbaden, Germany, 2018; ISBN 9783658215606 .

12. Energiewende im Überblick. Available online: https://www.bundesregierung.de/breg-de/themen/energiewende/energiewe nde-im-ueberblick-229564 (accessed on 15 June 2020).

13. International Energy Agency-Germany. Available online: https://www.iea.org/countries/germany (accessed on 13 January 2021).

14. Murray, L. The need to rethink German Nuclear Power. Electr. J. 2019, 32, 13-19. [CrossRef]

15. Suwała, W.; Wyrwa, A.; Olkuski, T. Trends in coal use-Global, EU and Poland. In IOP Conference Series: Materials Science and Engineering; IOP Publishing: Bristol, UK, 2017; Volume 268. [CrossRef]

16. Skoczkowski, T.; Bielecki, S.; Węglarz, A.; Włodarczak, M.; Gutowski, P. Impact assessment of climate policy on Poland's power sector. Mitig. Adapt. Strateg. Glob. Chang. 2018, 23, 1303-1349. [CrossRef]

17. Cianciara, A.K. Contestation of EU Climate Policy in Poland: Civil Society and Politics of National Interest. Prakseologia 2017, 159, 237-264.

18. Van der Linden, S. The social-psychological determinants of climate change risk perceptions: Towards a comprehensive model. J. Environ. Psychol. 2015, 41, 112-124. [CrossRef]

19. Gifford, R. The dragons of inaction: Psychological barriers that limit climate change mitigation and adaptation. Am. Psychol. 2011, 66, 290-302. [CrossRef]

20. Hornsey, M.J.; Harris, E.A.; Bain, P.G.; Fielding, K.S. Meta-analyses of the determinants and outcomes of belief in climate change. Nat. Clim. Chang. 2016, 6, 622-626. [CrossRef]

21. Dunlap, R.E. Climate Change Skepticism and Denial: An Introduction. Am. Behav. Sci. 2013, 57, 691-698. [CrossRef]

22. Leiserowitz, A.A.; Maibach, E.W. Climategate, public opinion, and the loss of trust. Am. Behav. Sci. 2013, 57, 818-837. [CrossRef]

23. Norgaard, K.M. "We Don't Really Want to Know": Environmental Justice and Socially Organized Denial of Global Warming in Norway. Organ. Environ. 2006, 19, 347-370. [CrossRef]

24. Norgaard, K.M. "People want to protect themselves a little bit": Emotions, denial, and social movement nonparticipation. Sociol. Inq. 2006, 76, 372-396. [CrossRef] 
25. Castán Broto, V.; Bulkeley, H. A survey of urban climate change experiments in 100 cities. Glob. Environ. Chang. 2013, 23, 92-102. [CrossRef]

26. Mead, E.; Roser-Renouf, C.; Rimal, R.N.; Flora, J.A.; Maibach, E.W.; Leiserowitz, A. Information Seeking about Global Climate Change among Adolescents: The Role of Risk Perceptions, Efficacy Beliefs and Parental Influences. Atl. J. Commun. 2012, 20, 31-52. [CrossRef]

27. Zeelenberg, M.; Nelissen, R.M.A.; Breugelmans, S.M.; Pieters, R. On emotion specificity in decision making: Why feeling is for doing. Judgm. Decis. Mak. 2008, 3, 18-27.

28. Ekman, P. An argument for basic emotions. Cogn. Emot. 1992, 6, 169-200. [CrossRef]

29. Smith, C.A.; Lazarus, R.S. Emotion and adaptation. In Handbook of Personality; Guilford: New York, NY, USA, 1990.

30. Marshall, G. Don't Even Think About It: Why Our Brains Are Wired to Ignore Climate Change; Bloomsbury USA: New York, NY, USA, 2015; ISBN 9781632861023.

31. Lewandowsky, S.; Ecker, U.K.H.; Seifert, C.M.; Schwarz, N.; Cook, J. Misinformation and Its Correction: Continued Influence and Successful Debiasing. Psychol. Sci. Public Interest 2012, 13, 106-131. [CrossRef]

32. Cook, J.; Ecker, U.; Lewandowsky, S. Misinformation and how to correct it. In Emerging Trends in the Social and Behavioral Sciences: An Interdisciplinary, Searchable, and Linkable Resource; Wiley Online Libray: Hoboken, NJ, USA, 2015. [CrossRef]

33. Sterman, J.D. Risk communication on climate: Mental models and mass balance. Science 2008, 322, 532-533. [CrossRef] [PubMed]

34. Malka, A.; Krosnick, J.A.; Langer, G. The association of knowledge with concern about global warming: Trusted information sources shape public thinking. Risk Anal. 2009, 29, 633-647. [CrossRef] [PubMed]

35. Ding, D.; Maibach, E.W.; Zhao, X.; Roser-Renouf, C.; Leiserowitz, A. Support for climate policy and societal action are linked to perceptions about scientific agreement. Nat. Clim. Chang. 2011, 1, 462-466. [CrossRef]

36. Krosnick, J.A.; Holbrook, A.L.; Lowe, L.; Visser, P.S. The Origins and Consequences of democratic citizens' Policy Agendas: A Study of Popular Concern about Global Warming. Clim. Chang. 2006, 77, 7-43. [CrossRef]

37. Hardin, G. The tragedy of the commons: The population problem has no technical solution; it requires a fundamental extension in morality. Science 1968, 162, 1243-1248. [CrossRef]

38. Ansari, S.; Wijen, F.; Gray, B. Constructing a Climate Change Logic: An Institutional Perspective on the "Tragedy of the Commons". Organ. Sci. 2013, 24, 1014-1040. [CrossRef]

39. Dunlap, R.E. Measuring Endorsement of the New Ecological Paradigm: A Revised NEP Scale. J. Soc. Issues 2000, 56, 425-442. [CrossRef]

40. Rhodes, E.; Axsen, J.; Jaccard, M. Exploring Citizen Support for Different Types of Climate Policy. Ecol. Econ. 2017, 137, 56-69. [CrossRef]

41. Zahran, S.; Brody, S.D.; Grover, H.; Vedlitz, A. Climate Change Vulnerability and Policy Support. Soc. Nat. Resour. 2006, 19, 771-789. [CrossRef]

42. Dietz, T.; Dan, A.; Shwom, R. Support for Climate Change Policy: Social Psychological and Social Structural Influences. Rural Sociol. 2007, 72, 185-214. [CrossRef]

43. O'Connor, R.E.; Bord, R.J.; Yarnal, B.; Wiefek, N. Who Wants to Reduce Greenhouse Gas Emissions? Soc. Sci. Q. 2002, 83, 1-17. [CrossRef]

44. Akter, S.; Bennett, J.; Ward, M.B. Climate Change Scepticism and Public Support for Mitigation: Evidence from an Australian Choice Experiment; Monash University, Department of Economics: Clayton, Australia, 2013.

45. Corner, A.J.; Whitmarsh, L.E.; Xenias, D. Uncertainty, scepticism and attitudes towards climate change: Biased assimilation and attitude polarisation. Clim. Chang. 2012, 114, 463-478. [CrossRef]

46. Weber, E.U.; Stern, P.C. Public understanding of climate change in the United States. Am. Psychol. 2011, 66, 315-328. [CrossRef] [PubMed]

47. Festinger, L. A Theory of Social Comparison Processes. Hum. Relat. 1954, 7, 117-140. [CrossRef]

48. Schultz, P.W.; Nolan, J.M.; Cialdini, R.B.; Goldstein, N.J.; Griskevicius, V. The constructive, destructive, and reconstructive power of social norms. Psychol. Sci. 2007, 18, 429-434. [CrossRef]

49. March, J.G. Primer on Decision Making: How Decisions Happen; Simon and Schuster: New York, NY, USA, 1994.

50. Ščasný, M.; Zvěřinová, I.; Czajkowski, M.; Kyselá, E.; Zagórska, K. Public acceptability of climate change mitigation policies: A discrete choice experiment. Clim. Policy 2017, 17, S111-S130. [CrossRef]

51. Kotchen, M.J.; Boyle, K.J.; Leiserowitz, A.A. Willingness-to-pay and policy-instrument choice for climate-change policy in the United States. Energy Policy 2013, 55, 617-625. [CrossRef]

52. Uehleke, R. The role of question format for the support for national climate change mitigation policies in Germany and the determinants of WTP. Energy Econ. 2016, 55, 148-156. [CrossRef]

53. Carlsson, F.; Kataria, M.; Krupnick, A.; Lampi, E.; Löfgren, Å.; Qin, P.; Chung, S.; Sterner, T. Paying for Mitigation: A Multiple Country Study; University of Gothenburg, Department of Economics: Gothenburg, Sweden, 2010.

54. Cameron, T.A. Individual option prices for climate change mitigation. J. Public Econ. 2005, 89, 283-301. [CrossRef]

55. Layton, D.F.; Brown, G. Heterogeneous Preferences Regarding Global Climate Change. Rev. Econ. Stat. 2000, 82, 616-624. [CrossRef]

56. Carson, R.; Czajkowski, M. The Discrete Choice Experiment Approach to Environmental Contingent Valuation. In Handbook of Choice Modelling; Edward Elgar: Cheltenham, UK, 2014. 
57. Arrow, K.; Solow, R.; Portney, P.R.; Leamer, E.E.; Radner, R.; Schuman, H. Report of the NOAA panel on contingent valuation. Fed. Regist. 1993, 58, 4601-4614.

58. Venkatachalam, L. The contingent valuation method: A review. Environ. Impact Assess. Rev. 2004, 24, 89-124. [CrossRef]

59. Nocera, S.; Telser, H.; Bonato, D. The Contingent Valuation Method in Health Care: An Economic Evaluation of Alzheimer's Disease; Springer Science \& Business Media: New York, NY, USA, 2012; ISBN 9781441991331.

60. Vossler, C.A.; Doyon, M.; Rondeau, D. Truth in Consequentiality: Theory and Field Evidence on Discrete Choice Experiments. Am. Econ. J. Microecon. 2012, 4, 145-171. [CrossRef]

61. Czajkowski, M.; Vossler, C.A.; Budziński, W.; Wiśniewska, A.; Zawojska, E. Addressing empirical challenges related to the incentive compatibility of stated preferences methods. J. Econ. Behav. Organ. 2017, 142, 47-63. [CrossRef]

62. Whitmarsh, L. Scepticism and uncertainty about climate change: Dimensions, determinants and change over time. Glob. Environ. Chang. 2011, 21, 690-700. [CrossRef]

63. Frederick, S. Cognitive Reflection and Decision Making. J. Econ. Perspect. 2005, 19, 25-42. [CrossRef]

64. Brañas-Garza, P.; Kujal, P.; Lenkei, B. Cognitive reflection test: Whom, how, when. J. Behav. Exp. Econ. 2019, 82, 101455. [CrossRef]

65. Bernauer, T.; Gampfer, R. How robust is public support for unilateral climate policy? Environ. Sci. Policy 2015, 54, 316-330. [CrossRef]

66. Brannlund, R.; Persson, L. To tax, or not to tax: Preferences for climate policy attributes. Clim. Policy 2012, 12, 704-721. [CrossRef]

67. Kallbekken, S.; Sælen, H. Public acceptance for environmental taxes: Self-interest, environmental and distributional concerns. Energy Policy 2011, 39, 2966-2973. [CrossRef]

68. Hansen, J.E. Environment and development challenges: The imperative of a carbon fee and dividend. In The Oxford Handbook of the Macroeconomics of Global Warming; Oxford University Press: Oxford, UK, 2015.

69. Mackie, A.; Haščič, I. The Distributional Aspects of Environmental Quality and Environmental Policies: Opportunities for Individuals and Households; OECD Green Growth Papers; OECD: Paris, France, 2019. 